\title{
MIKROZONASI SEISMIK WILAYAH KOTA PADANG BERDASARKAN PENGUKURAN MIKROTREMOR
}

\section{SEISMIC MICROZONATION OF PADANG CITY BASED ON MICROTREMOR MEASUREMENTS}

\section{Adrin Tohari, Dadan Dani Wardhana}

Pusat Penelitian Geoteknologi, LIPI, Jl. Sangkuriang Bandung 40135

\begin{abstract}
ABSTRAK Peristiwa gempa bumi pada tanggal 30 September 2009, dengan skala intensitas VIIVIII, mengindikasikan bahwa wilayah Kota Padang rentan terhadap amplifikasi tanah. Makalah ini menyajikan hasil analisis rasio spektra $\mathrm{H} / \mathrm{V}$ untuk menghasilkan mikrozonasi kerentanan amplifikasi berdasarkan pengukuran mikrotremor. Hasil analisis menunjukkan variasi nilai periode predominan dan faktor amplifikasi yang dipengaruhi oleh jenis lapisan tanah dan struktur bawah permukaan. Berdasarkan variasi nilai faktor amplifikasi, wilayah Kota Padang dapat diklasifikasikan menjadi 5 (lima) zonasi kerentanan amplifikasi. Kawasan perumahan kepadatan tinggi, perdagangan dan perkantoran di wilayah kecamatan Nanggalo, Padang Utara, Padang Barat dan Padang Selatan berada di zona kerentanan tinggi hingga sangat tinggi terhadap bahaya amplifikasi. Hasil zonasi ini sesuai dengan fakta-fakta kerusakan bangunan akibat fenomena amplifikasi yang terjadi pada gempa bumi 30 September 2009.
\end{abstract}

Kata kunci: amplifikasi tanah, gempa bumi, kerentanan, mikrotremor, mikrozonasi, periode predominan, rasio spektral $\mathrm{H} / \mathrm{V}$.

Naskah masuk : 1 Agustus 2018

Naskah direvisi : 17 Oktober 2018

Naskah diterima : 19 Oktober 2018

Adrin Tohari

Pusat Penelitian Geoteknologi, LIPI

Jl. Sangkuriang Bandung 40135

Email : adrin.tohari@gmail.com
ABSTRACT The 30 September 2009 earthquake event with intensity VII to VIII (MMI scale) indicated that Padang City region is prone to soil amplification. This paper presents the results of $H / V$ spectral ratio analysis to produce a microzonation map of amplification for Padang City based on microtremor measurement. The analysis of microtremor data shows that the predominant period and amplification factor of the soils are spatially varied and influenced by soil types and subsurface structure. On the basis of amplification factor, Padang City is classified into 5 (five) zones. High and very high susceptible zones are mainly concentrated in the very dense residential areas, trade and office areas, including the districts of Nanggalo, Padang Utara, Padang Barat, and Padang Selatan. The predicted amplification susceptibility zones are in a good agreement with the phenomena of building damages due to amplification during the 2009 earthquake.

Keywords: Earthquake, microzonation, microtremor, predominant period, susceptibility, soil amplification, $H / V$ spectral ratio.

\section{PENDAHULUAN}

Peristiwa gempa bumi sering kali menimbulkan kerusakan pada bangunan yang terletak jauh dari sumber gempa. Perbedaan tingkat kerusakan pada bangunan mengindikasikan bahwa kondisi lapisan tanah memberikan pengaruh yang nyata terhadap karakteristik gelombang seismik selama gempa. Vibrasi struktur bangunan di permukaan tanah sangat dipengaruhi oleh periode predominan, sehingga fenomena amplifikasi frekuensi getaran gempa akan meningkatkan kerusakan pada bangunan. Kondisi ini dapat terjadi dengan sangat ekstrem di wilayah cekungan batuan yang terisi oleh lapisan tanah lunak yang tebal, sehingga 

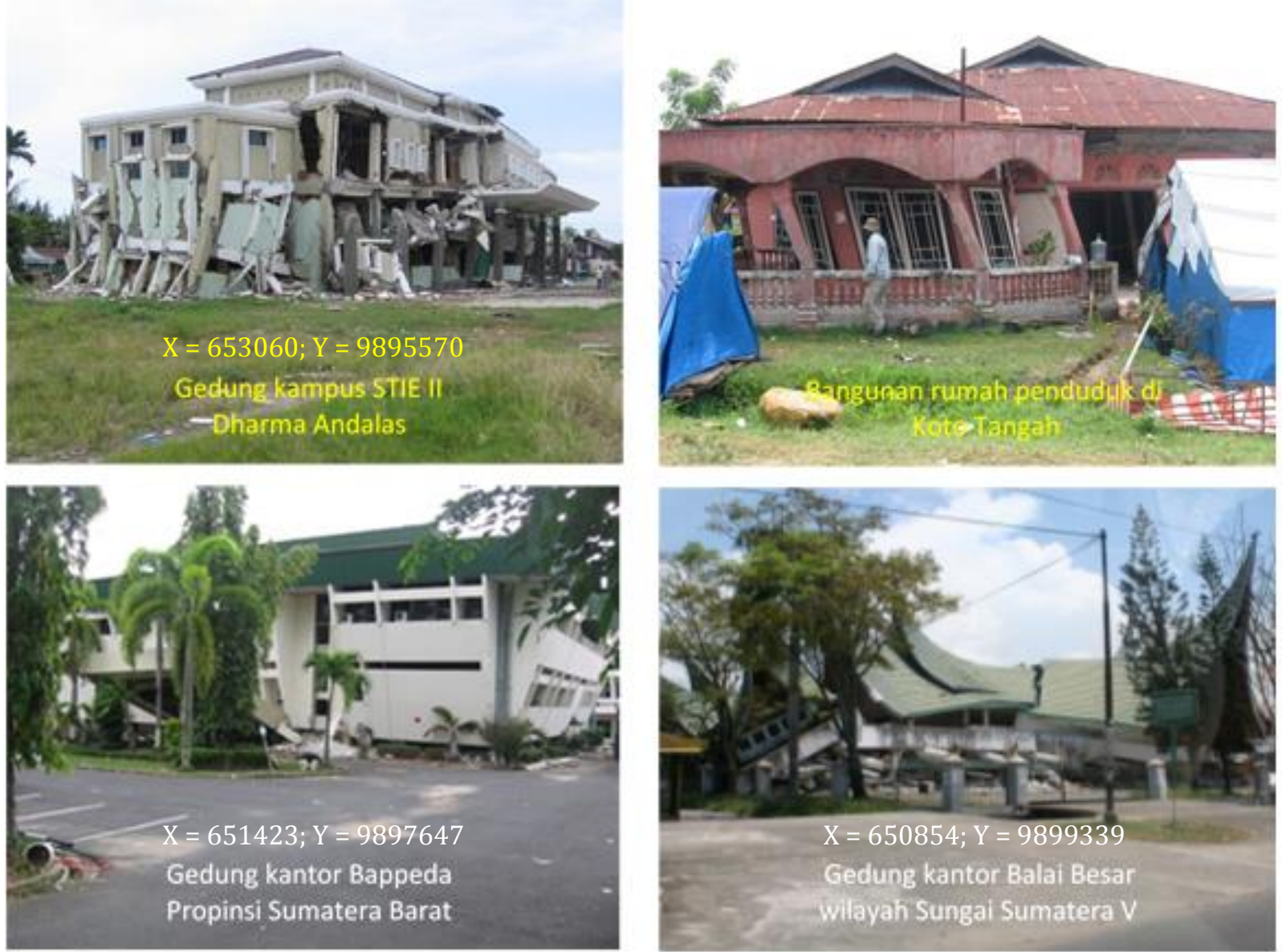

Gambar 1. Contoh kerusakan bangunan di Kota Padang akibat fenomena amplifikasi getaran gempa bumi 30 September 2009.

terdapat perubahan kekakuan material pada batas antara lapisan batuan dan tanah lunak yang dapat menimbulkan amplifikasi kuat, seperti yang terjadi di Kota Meksiko akibat gempa bumi Michoachan pada tahun 1985 (Seed et al., 1988).

Kota Padang merupakan salah satu wilayah kota pesisir yang rentan terhadap bahaya gempa bumi besar dari aktifitas tektonik pada zona subduksi di sebelah barat wilayah ini. Salah satu peristiwa gempa bumi yang terjadi tahun 2009 (MMI VIIVIII) mengakibatkan kerusakan ringan hingga berat pada bangunan rumah timggal dan gedung bertingkat milik pemerintah maupun swasta di Kota Padang (Gambar 1). Kerusakan pada bangunan tersebut bersifat lokal; hanya terjadi pada beberapa wilayah. Hal ini mengindikasikan kondisi lapisan tanah di Kota Padang mengontrol derajat kerusakan bangunan akibat getaran seismic selama gempa bumi tersebut. Penelitian yang dilakukan oleh Tohari et al. (2011) menunjukkan lapisan batuan sedimen di wilayah pesisir, hingga kedalaman $30 \mathrm{~m}$, tersusun oleh lapisan pasir dengan kepadatan yang bervariasi dari lepas hingga padat dan lapisan lempung lunak. Keberadaan lapisan tanah lunak ini dapat mengamplifikasi getaran tanah seismik selama gempa bumi tersebut dengan efek yang akan bervariasi dari satu lokasi ke lokasi lainnya. Mempertimbangkan tatanan geologi dan seismisitas wilayah Kota Padang, maka perlu dilakukan studi mikrozonasi seismik untuk mengkaji efek kondisi geologi lokal terhadap getaran tanah akibat peristiwa gempa secara kuantitatif. Mikrozonasi seismik sangat diperlukan di wilayah ini untuk mendukung kajian bahaya dan risiko seismik dan untuk menyediakan data yang diperlukan untuk rancangan bangunan tahan gempa dan struktur perkuatan dari bangunan yang sudah ada.

Kajian mikrozonasi seismik dapat dilakukan dengan menggunakan bermacam-macam metodologi yang telah berkembang selama 
beberapa puluh tahun belakangan ini. Mikrozonasi seismik biasanya dilakukan pada 3 level, yaitu level persiapan (level 1), yang menggunakan data eksisting, kemudian level tengah (level 2), yang menggunakan metode sederhana dan rumusan empirikal untuk mengkaji amplifikasi getaran tanah, dan level tertinggi (level 3), yang melibatkan metode-metode terkini untuk karakterisasi lapisan sedimen dan menerapkan metode numerik untuk menurunkan faktor-faktor amplifikasi (Bramerini et al., 2015). Mikrozonasi seismik pada level 3 menyediakan data yang diperlukan untuk rancangan tanah gempa dan struktur perkuatan bangunan eksisting. Di antara metode geoteknik dan geofisika yang digunakan untuk mikrozonasi level 3, metode mikrotremor telah banyak digunakan beberapa puluh tahun belakangan ini, karena metode ini menyediakan data periode atau frekuensi resonansi utama untuk lapisan tanah sedimen di atas batuan dasar menggunakan perhitungan rasio spektral horizontal terhadap vertikal menurut Nakamura (1989). Akan tetapi, metode mikrotremor ini hanya akan memberikan hasil jika terdapat perbedaan impedansi yang kuat antara lapisan sedimen dan batuan dasar (Ansal, 2004). Beberapa peneliti terdahulu telah menggunakan metode mikrotremor untuk mengevaluasi efek tapak dan menghasilkan peta mikrozonasi seismik (Fallahi et al., 2003; Tuladhar et al., 2004; Davenport dan Stephenson, 2005; Bonnefoy-Claudet et al., 2008; Gosar, 2009; Claprood dan Asten, 2009; Eskisar et al., 2013).

Penelitian mikrozonasi seismik di Kota Padang telah dilakukan oleh beberapa peneliti pasca gempa bumi tahun 2009. Menggunakan metode mikrotremor stasiun tunggal (single station microtremor), Kamawan et al. (2009) melakukan pengukuran mikrotremor di sebagian wilayah Kota Padang pada koordinat $100^{\circ} 20^{\prime}-100^{\circ} 29^{\prime}$ BT dan $0^{\circ} 52^{\prime}-1^{\circ} 00^{\prime}$ LS. Untuk daerah yang terbatas ini, hasil pengelompokan nilai amplifikasi mengindikasikan bahwa lebih dari setengah luas wilayah studi mempunyai amplifikasi tinggi hingga sangat tinggi, dan lahan-lahan yang mempunyai faktor amplifikasi lebih dari 6 kali menyebabkan bangunan di atasnya mengalami kerusakan pada gempa Padang 30 September 2009. Kiyono et al. (2010) melakukan pemetaan struktur bawah permukaan dengan menggunakan mikrotremor tunggal (single microtremor), dengan frekuensi pengambilan data $100 \mathrm{~Hz}$ atau
$500 \mathrm{~Hz}$, pada 129 lokasi yang tersebar di wilayah Kota Padang. Mereka menyimpulkan bahwa lapisan tanah yang dalam dengan periode 2 hingga 3 detik menyebar sepanjang pantai. Pada lokasi mendekati daerah perbukitan di sebelah timur dan selatan kota Padang terdapat perubahan periode predominan yang drastis yang kemungkinan mengindikasikan keberadaan sesar/ sesar yang tersembunyi (hidden fault).

Mempertimbangkan tatanan geologi dan seismisitas, maka perlu dilakukan studi mikrozonasi seismik yang mencakup seluruh daerah di wilayah Kota Padang, termasuk daerah perbukitan di sebelah timur dan wilayah pesisir di sebelah utara. Mikrozonasi ini sangat diperlukan untuk mendukung kajian bahaya dan risiko seismik dan untuk menyediakan data yang diperlukan untuk rancangan bangunan tahan gempa dan perkuatan struktur dari bangunan yang sudah ada di wilayah Kota Padang. Makalah ini menyajikan hasil kajian kerentanan seismik berdasarkan metode mikrotremor di wilayah Kota Padang. Adapun sasaran dari kajian ini adalah untuk (1) mengetahui sebaran nilai periode predominan tanah dan faktor amplifikasi tanah berdasarkan rasio respon spektra (HVSR), (2) mengkaji faktor yang mempengaruhi respon spectra tanah dan (3) menyusun peta mikrozonasi kerentanan seismik berdasarkan hasil pengukuran mikrotremor dengan memperhatikan tingkat kerusakan bangunan akibat gempa bumi tahun 2009.

\section{KONDISI GEOLOGI DAN SEISMO- TEKTONIK WILAYAH KOTA PADANG}

\section{Kondisi Geologi}

Berdasarkan peta geologi lembar Padang (Kastowo et al., 1973), wilayah Kota Padang tersusun oleh 4 (empat) lapisan batuan, yang terdiri dari batuan sedimen berumur Jura, batuan gunung api berumur kuarter dan batuan sedimen berumur kuarter (Gambar 2). Batuan sedimen tua terdiri dari batugamping (Jl) dan sedimen yang termetamorf (Js). Batuan gunungapi terdiri dari tuf andesitik dan basaltik, breksi (QTt) dan lava (QTau). Batuan ini terdapat di wilayah perbukitan bagian selatan dan timur. Batuan gunungapi yang lebih muda (Qf) tersusun oleh material rombakan andesit berasal batuan gunungapi QTau yang terdapat pada lereng-lereng gunungapi Kuarter di wilayah perbukitan bagian timur. Batuan termuda di wilayah Kota Padang adalah endapan aluvial 


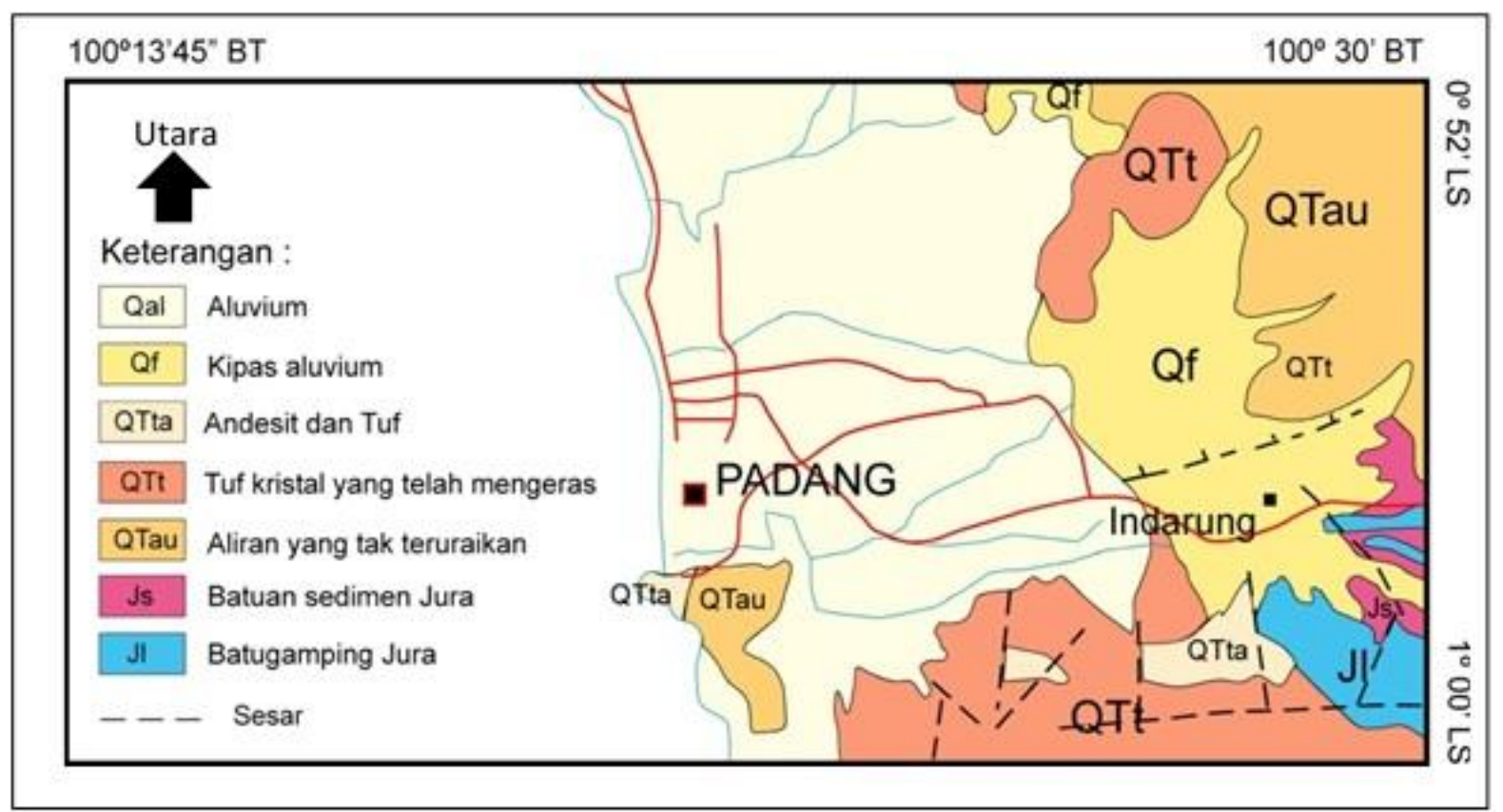

Gambar 2. Peta Geologi Kota Padang dan sekitarnya (Kastowo dkk., 1996).

kuarter (Qa), yang terdiri dari lapisan pasir, lanau, kerikil dan lapisan endapan rawa yang tebal. Endapan ini membentuk dataran aluvial dari kaki perbukitan dengan lebar $10 \mathrm{~km}$ pada arah barattimur dan $20 \mathrm{~km}$ pada arah utara-selatan.

\section{Kondisi Seismo-Tektonik}

Kota Padang terletak $250 \mathrm{~km}$ sebelah timur dari zona subduksi Sumatera, yang terbentuk akibat penujaman lempeng Indo-Australia ke bawah Lempeng Eurasia, dengan laju rata-rata 50-70 $\mathrm{mm} /$ tahun (Prawirodirdjo et al., 2000; Natawidjaja et al., 2004). Konvergensi miring terbagi menjadi dua komponen, yaitu komponen dip slip yang terakomodasi oleh interfase subduksi dan komponen strike-slip yang diakomodasi oleh sesar Sumatera (McCaffrey, 1991; Sieh and Natawidjaja, 2000)

Beberapa gempa bumi besar tercatat pernah terjadi di zona subduksi Sumatera salah satunya adalah gempa bumi yang terjadi pada tahun 2009 dengan magnitude sebesar 7,6 (Mw). Pusat gempa terletak di lepas pantai sekitar $60 \mathrm{~km}$ sebelah baratbaratlaut dari Kota Padang, pada kedalaman sekitar $80 \mathrm{~km}$ di dasar samudera pada Lempeng Indo-Australia. Selama gempa, percepatan getaran puncak di permukaan tanah sebesar $0,3 \mathrm{~g}$ tercatat di stasiun geofisika yang diberi nama PDSI di Kota Padang. Karena lokasi stasiun ini terletak di daerah perbukitan Limau Manis, sekitar $12 \mathrm{~km}$ dari pantai dan pada lapisan tanah padat, getaran seismik di pusat Kota Padang, yang berada di endapan tanah lunak, kemungkinan besar mempunyai nilai percepatan getaran puncak di permukaan tanah yang lebih besar (EERI, 2009).

Sementara itu, Zona Sesar Sumatera sepanjang $1900 \mathrm{~km}$ terbagi atas 20 segmen dengan laju pergeseran berkisar 10 hingga $26 \mathrm{~mm} /$ tahun dan meningkatkan ke barat laut (Natawidjaja dan Triyoso, 2007). Sejak tahun 1890, sekitar 21 peristiwa gempa bumi besar telah terjadi di sepanjang zona sesar ini (Sieh and Natawidjaja, 2000). Beberapa diantaranya terjadi di segmensegmen yang terletak di wilayah Sumatera Barat, seperti di segmen Sianok pada tahun 1926 (Ms 7), dan di segmen Sumani pada tahun 1926 (Ms 7), tahun 1943 (Ms 7.6) dan 2007 (Mw 6.4).

\section{METODE}

\section{Pengambilan Data Mikrotremor}

Pengukuran mikrotremor dilakukan pada 499 titik yang tersebar di wilayah seluas $+125 \mathrm{~km}^{2}$ dari pesisir di sebelah barat dan wilayah perbukitan di sebelah timur, dengan spasi antar titik pengukuran berkisar 1-2 km (Gambar 3). Pengukuran mikrotremor dilakukan dengan peralatan mikrotremor tunggal (single microtremor), yang terdiri dari sensor kecepatan (velocity-meter) merk Geodaqs (Geophysical Data Acquisition) 


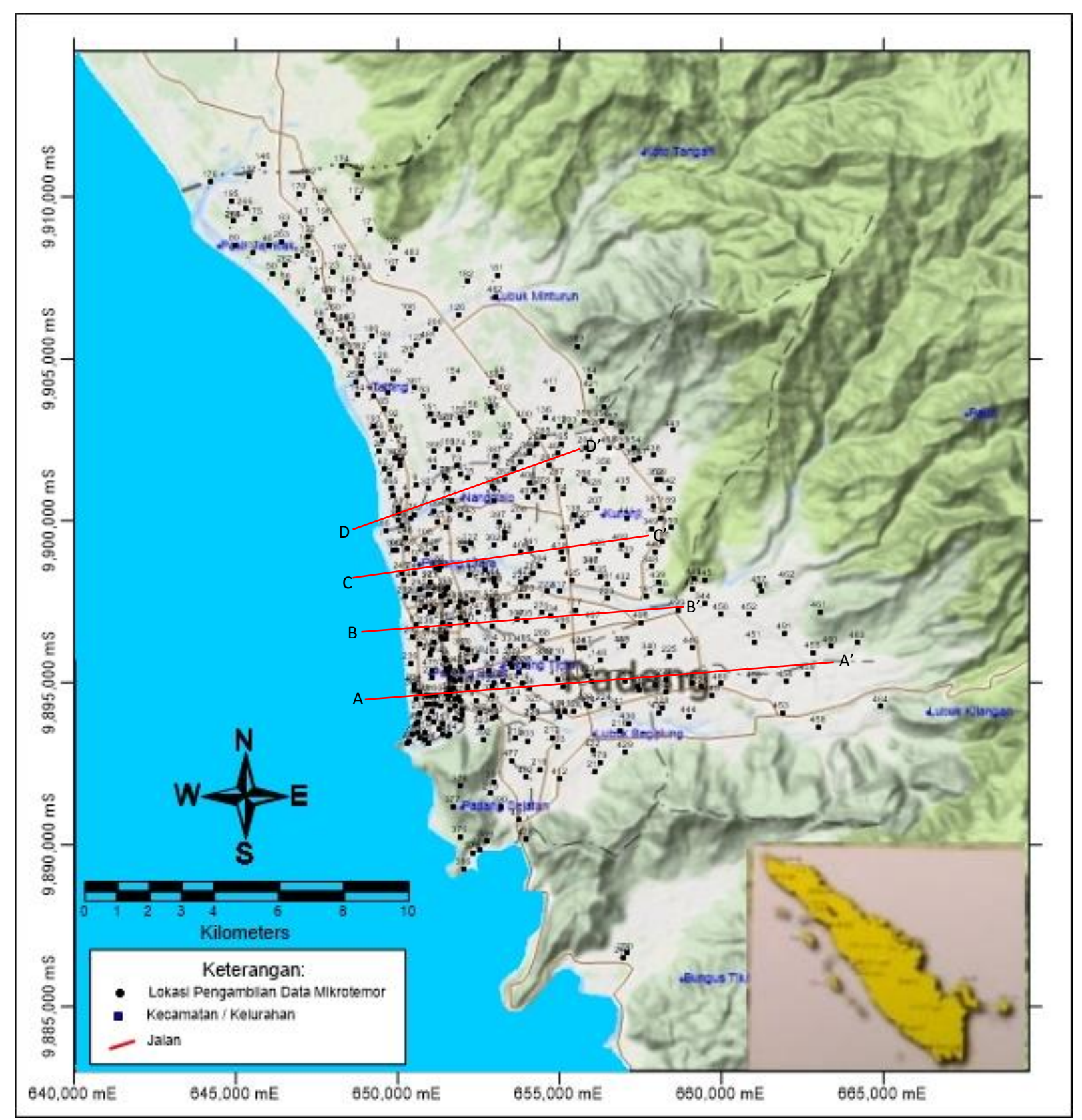

Gambar 3. Peta lokasi pengambilan data mikrotremor.

buatan Butan Service Co, Jepang, dan global positioning system (GPS) untuk mencatat koordinator lokasi pengukuran.

Sensor kecepatan mengukur tiga komponen getaran di 1 lokasi, yaitu 2 komponen horizontal (Utara-Selatan dan Barat-Timur) dan 1 komponen vertikal (atas-bawah). Jangkauan response frekuensi sensor adalah $0,1-20 \mathrm{~Hz}$. Pengambilan data pada semua titik pengukuran diatur pada frekuensi $100 \mathrm{~Hz}$. Pengukuran mikrotremor dilakukan di siang hari pada lapisan tanah asli, dan disesuaikan dengan kondisi di lapangan (jauh dari jalan raya, dan kedalaman muka air tanah $>2 \mathrm{~m}$ ). Jangka waktu pengambilan data di setiap lokasi selama 660 detik. Semua waktu pengukuran disinkronasikan dengan menggunakan waktu referensi pada alat GPS yang terhubung dengan alat mikrotremor.

\section{Pengolahan Data}

Pengolahan data mikrotremor dilakukan dengan menggunakan software Geonet. Data rekaman waktu akan dibagi menjadi 33 segmen, dengan 
durasi 20 detik. Untuk setiap lokasi, 20 segmen data dipilih dari 33 segmen, dengan memilih segmen-segmen yang bebas dari pengaruh sumber-sumber getaran yang tidak diinginkan seperti kendaraan bermotor. Dua puluh segmen ini digunakan untuk perhitungan. Spektra Fourier dihitung untuk segmen-segmen terpilih tersebut menggunakan algoritma Fast Fourier Transform (FFT). Rasio amplitudo Fourier dari dua spektra Fourier horizontal dan 1 spektra Fourier vertikal didapatkan berdasarkan persamaan di bawah ini:

$$
r(f)=\frac{\sqrt{F_{N S}(f)+F_{E W}(f)}}{F_{U D}(f)}
$$

, dimana $r(f)$ adalah rasio spektrum horizontal dan vertikal $(\mathrm{H} / \mathrm{V})$, dan $\mathrm{F}_{N S}, \mathrm{~F}_{E W}$ dan $\mathrm{F}_{U D}$ masingmasing adalah spektra amplitudo Fourier untuk arah utara-selatan, timur-barat dan atas-bawah. Setelah spektra H/V untuk 20 segmen didapatkan, maka spektrum $\mathrm{H} / \mathrm{V}$ untuk setiap lokasi didapatkan dari rata-rata spektra untuk 20 segmen tersebut. Perbedaan impedansi yang jelas antara lapisan tanah dan batuan dasar ditunjukkan dengan pemunculan suatu puncak pada kurva rasio spektral $(\mathrm{H} / \mathrm{V})$ yang merupakan nilai periode predominan tanah. Berdasarkan hasil pengolahan semua data pengukuran kemudian dilakukan pembuatan peta kontur untuk periode predominan dan faktor amplifikasi.

\section{HASIL DAN PEMBAHASAN}

\section{Karakteristik rasio spektral $\mathrm{H} / \mathrm{V}$}

Analisa 499 data mikrotremor dilakukan dengan menggunakan metode rasio spektral $\mathrm{H} / \mathrm{V}$ untuk memperoleh periode predominan lapisan tanah di Kota Padang. Hasil Analisa menunjukkan bahwa spektra H/V lapisan tanah dapat diklasifikasikan menjadi 3 jenis berdasarkan bentuk dari spektranya, yaitu (lihat Gambar 4):

- Jenis A - spektra H/V dengan satu puncak [Gambar 4(a)]

- Jenis B - spektra H/V dengan dua puncak yang berbeda [Gambar 4(b) dan 4(d)]

- Jenis C - spektra H/V tanpa puncak [Gambar 4(c)].

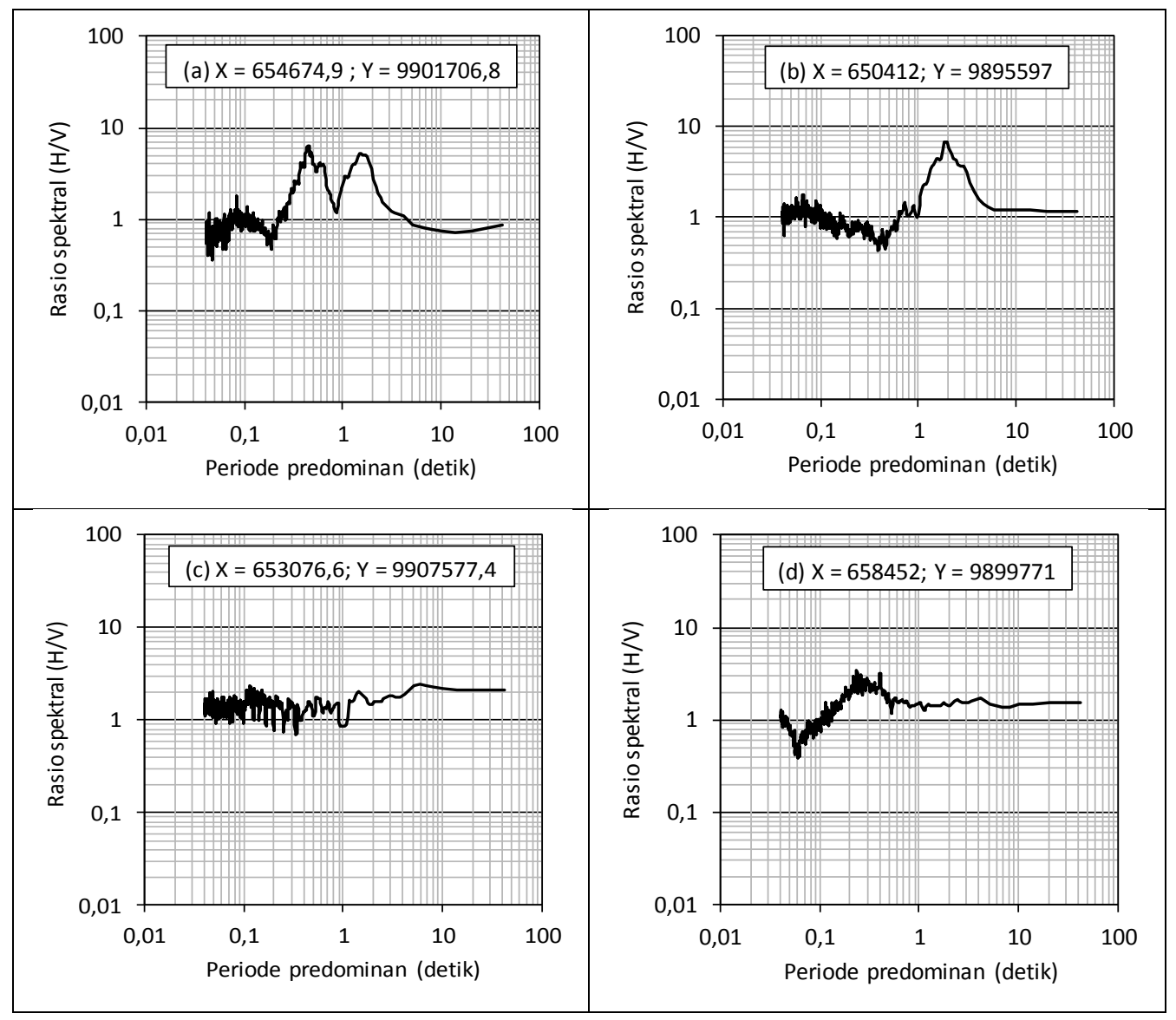

Gambar 4. Jenis-jenis rasio spektra H/V lapisan tanah di wilayah Kota Padang. 


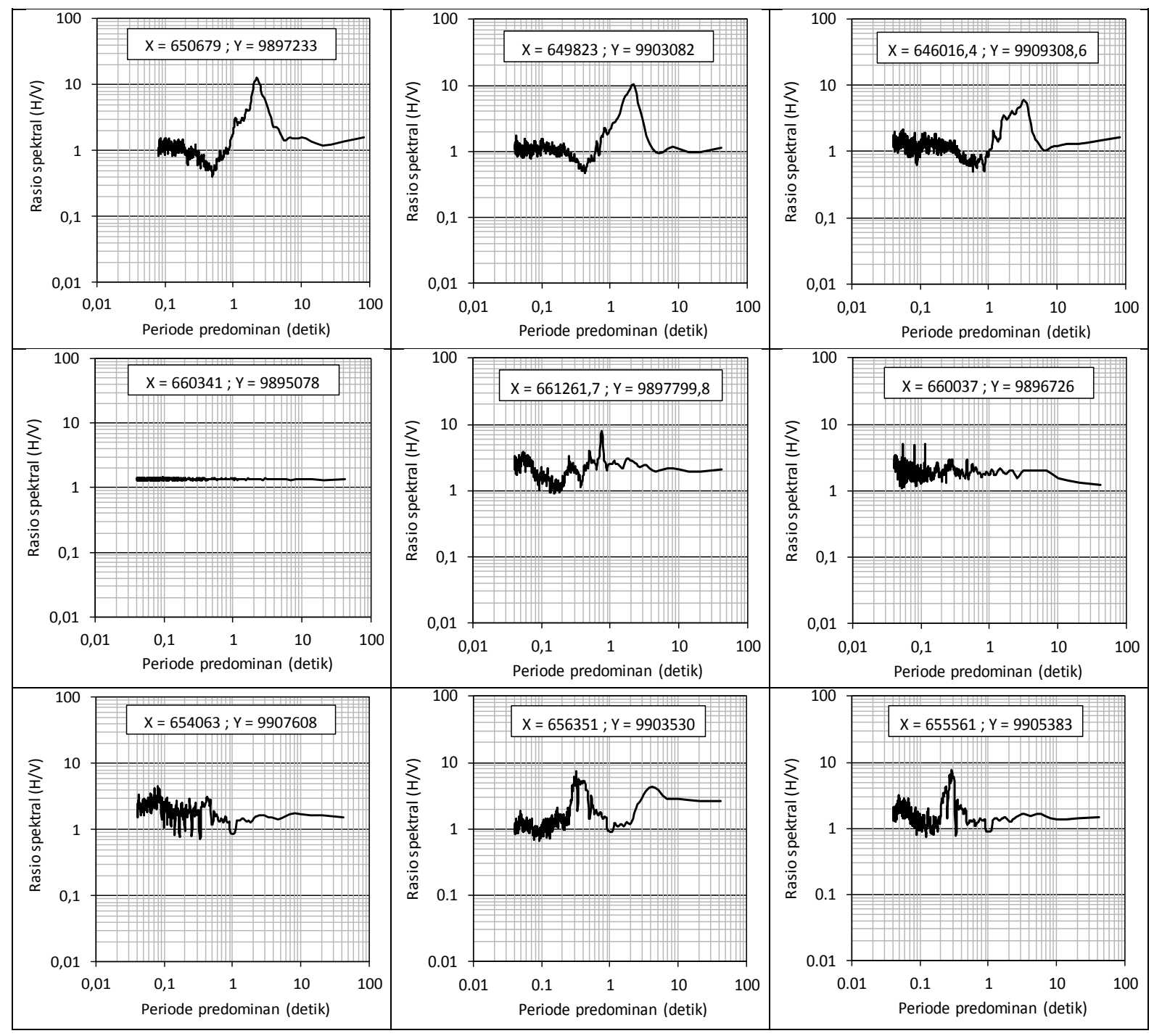

Gambar 5. Rasio spektra H/V berdasarkan jenis lapisan tanah di wilayah Kota Padang: dataran aluvial (atas), dataran kipas aluvial (tengah) dan perbukitan vulkanik (bawah).

Perbedaan bentuk rasio spektral $\mathrm{H} / \mathrm{V}$ di atas dipengaruhi oleh kedalaman lapisan tanah. Rasio spektral H/V jenis A (Gambar 4(a)), yang dicirikan dengan periode predominan pendek dan panjang yang masing-masing terasosiasi dengan lapisan tanah pada kedalaman dangkal dan lapisan tanah yang dalam. Pada rasio spektral $\mathrm{H} / \mathrm{V}$ jenis $\mathrm{B}$, pengaruh lapisan aluvial pada kedalaman yang berbeda tidak dapat dibedakan. Periode predominan tanah dapat menyajikan pengaruh lapisan tanah pada kedalaman dalam (Gambar 4(b)) atau oleh lapisan tanah dangkal (Gambar 4(d)). Sedangkan rasio spektral $\mathrm{H} / \mathrm{V}$ jenis $\mathrm{C}$ menyajikan pengaruh lapisan tanah padat di bawah permukaan tanah. Selain faktor kedalaman lapisan tanah, jenis lapisan tanah juga mempengaruhi karakteristik rasio spectral $\mathrm{H} / \mathrm{V}$.
Berdasarkan kondisi geologi dan geomorfologi, lokasi pengukuran mikrotremor dapat diklasifikasikan menjadi 3 (tiga) jenis yaitu daerah dataran yang tersusun oleh endapan aluvial, daerah lereng landai yang terbentuk oleh material kipas aluvial, dan daerah perbukitan yang tersusun oleh lapisan tanah hasil pelapukan batuan vulkanik. Gambar 5 menyajikan perbandingan beberapa kurva rasio spektral pada lapisan tanah yang terbentuk oleh endapan aluvial (atas), endapan kipas aluvial (tengah) dan tanah vulkanik (bawah). Rasio spektral lapisan aluvial mempunyai puncak yang jelas dan lebih tinggi dibandingkan spekral lapisan endapan kipas aluvial dan material vulkanik. Nilai periode predominan lapisan tanah aluvial mempunyai rentang yang lebih besar dan nilai amplifikasi 
puncak yang lebih tinggi dari pada lapisan tanah kipas aluvial dan material vulkanik. Sementara itu, lapisan kipas aluvial cenderung menunjukkan respon spektral yang agak datar dengan puncak yang sangat rendah sehingga nilai periode predominan tanah dan amplifikasi pada beberapa lokasi pengukuran tidak dapat ditentukan. Sedangkan spektral H/V lapisan material vulkanik cenderung mempunyai beberapa puncak dengan nilai periode predominan kurang dari 1 detik.

\section{Sebaran periode predominan dan faktor amplikasi $(\mathrm{H} / \mathrm{V})$}

Gambar 6 menyajikan kontur nilai periode predominan lapisan tanah di wilayah Kota Padang. Nilai periode predominan lapisan tanah sangat bervariasi, umumnya berkisar antara 0,5 hingga 3,5 detik. Nilai periode predominan rendah ( $\mathrm{T}<0,4$ detik) umumnya terdeteksi pada lapisan tanah aluvial di bagian timur dan daerah perbukitan vulkanik kuarter. Sementara itu, nilai periode predominan lapisan aluvial di wilayah tengah dan lapisan kipas aluvial berkisar antara
1,0 dan 2,0 detik. Sedangkan rasio spektral lapisan aluvial di bagian barat (pesisir pantai) cenderung mempunyai puncak dengan nilai periode predominan lebih besar dari 2,0 detik.

Gambar 7 menyajikan peta kontur nilai faktor amplifikasi (H/V) puncak lapisan tanah dan lokasi bangunan-bangun bertingkat yang mengalami kerusakan sedang hingga total. Nilai amplifikasi tanah berkisar antara 0 hingga 15 . Wilayah perbukitan yang tersusun oleh lapisan material vulkanik mempunyai nilai amplifikasi lebih rendah (kurang dari 4,0) dibandingkan daerah dataran yang tersusun oleh lapisan aluvial. Endapan aluvial di daerah pantai cenderung memiliki nilai amplifikasi berkisar antara 3,0 dan 6,0. Sementara itu, lapisan endapan aluvial di beberapa daerah di wilayah Kota Padang bagian tengah dan bagian selatan mempunyai nilai amplifikasi yang lebih besar dari 6,0. Hal ini mengindikasikan bahwa lapisan aluvial di wilayah selatan cenderung mempunyai karakteristik yang sama dengan lapisan alluvial di wilayah Kota Padang bagian tengah. Berdasarkan Tohari et al.

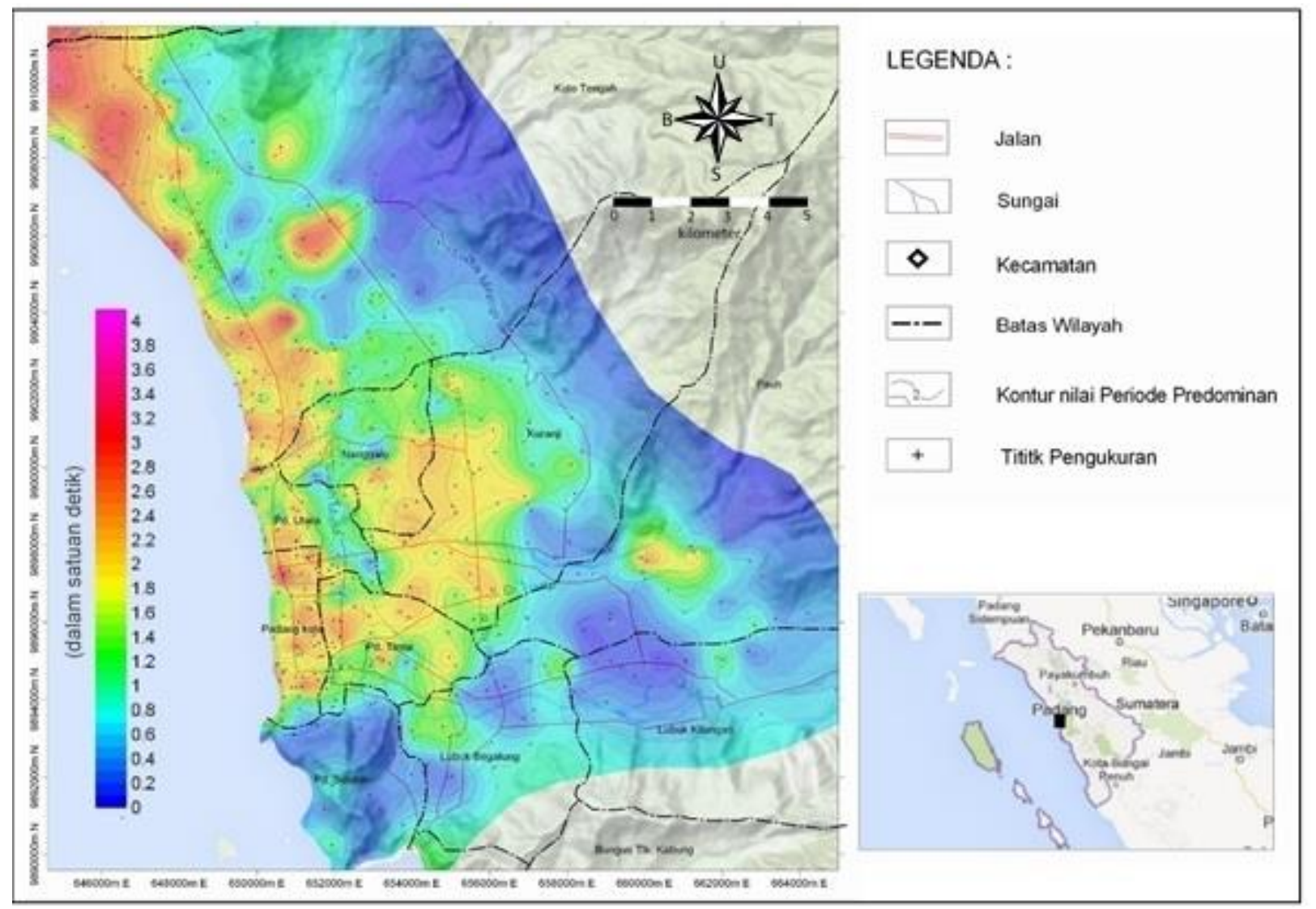

Gambar 6. Peta kontur periode predominan tanah wilayah Kota Padang. 


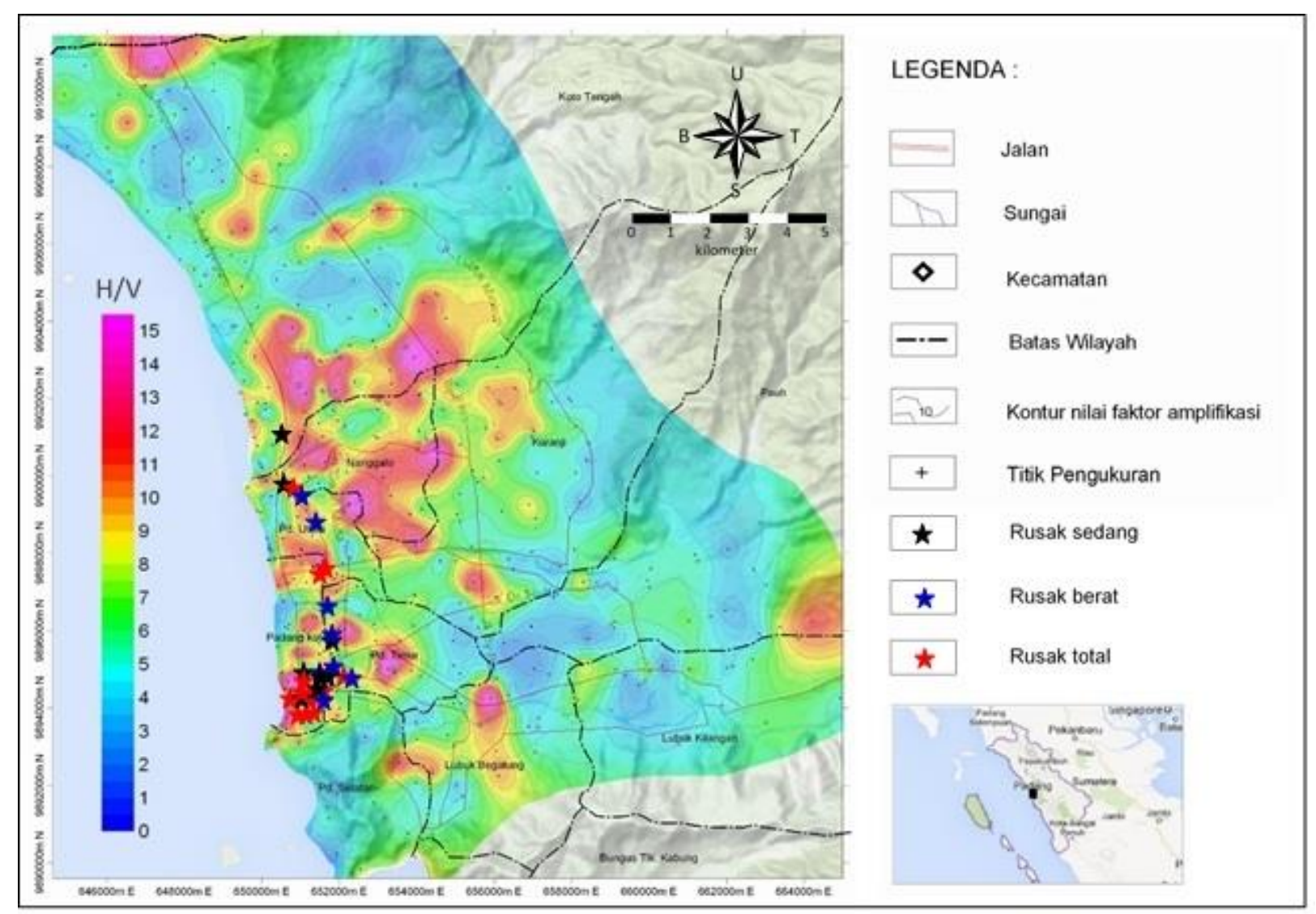

Gambar 7. Peta kontur faktor amplifikasi (H/V) tanah wilayah Kota Padang.

(2011), endapan aluvial di wilayah Kota Padang bagian tengah umumnya didominasi oleh lapisan endapan lanau dan lempung lunak yang cukup tebal di bawah permukaan tanah. Sementara itu, lapisan tanah di daerah pesisir pantai di dominasi oleh lapisan pasir medium hingga padat. Dengan demikian, endapan aluvial di wilayah Kota Padang mempunyai variasi respon spektral yang bergantung dari jenis lapisan tanah yang dominan di dalam endapan aluvial di setiap lokasi pengukuran.

Gambar 7 juga mengindikasikan bahwa bangunan-bangunan bertingkat (2 lantai atau lebih) yang rusak berat hingga runtuh umumnya berada berada di wilayah pesisir bagian selatan. Tabel 1 menyajikan karakteristik dinamika lapisan tanah di lokasi-lokasi bangunan tinggi yang rusak berat dan runtuh yang dicirikan oleh nilai periode predominan lebih dari 1,5 detik dan nilai faktor amplifikasi lebih besar dari 8. Hal yang menarik untuk dicatat adalah lokasi-lokasi bangunan tersebut umumnya berada dalam 1 garis lurus dengan arah utara-selatan, tepatnya di sepanjang jalan Khatib Sulaiman di Kecamatan Padang
Utara dan juga di sepanjang Jalan Gereja di Kecamatan Padang Barat. Dengan demikian, lapisan aluvial di wilayah tersebut lebih rentan terhadap amplifikasi getaran gempa bumi di bandingkan dengan lapisan aluvial di wilayah pesisir bagian utara.

\section{Pengaruh struktur bawah permukaan terhadap respon spectra}

Pada daerah dataran dengan lapisan endapan yang tebal, seperti di wilayah Kota Padang, struktur bawah permukaan mengontrol ketebalan lapisan endapan aluvial. Berdasarkan informasi geologi dan kemiringan lereng, kedalaman lapisan batuan dasar meningkat ke arah barat-barat daya. Dengan demikian lapisan aluvial, umumnya, akan semakin tebal ke arah tersebut. Akan tetapi, berdasarkan hasil analisis data mikrotremor, rasio spektral H/V sangat berbeda di setiap lokasi pengukuran sehingga lapisan tanah aluvial di wilayah Kota Padang mempunyai ketebalan yang bervariasi. $\mathrm{Hal}$ ini mengindikasikan pengaruh struktur bawah permukaan yang kuat terhadap variasi ketebalan lapisan tanah aluvial sehingga sifat dinamik tanah alluvial menjadi bervariasi di setiap lokasi. 

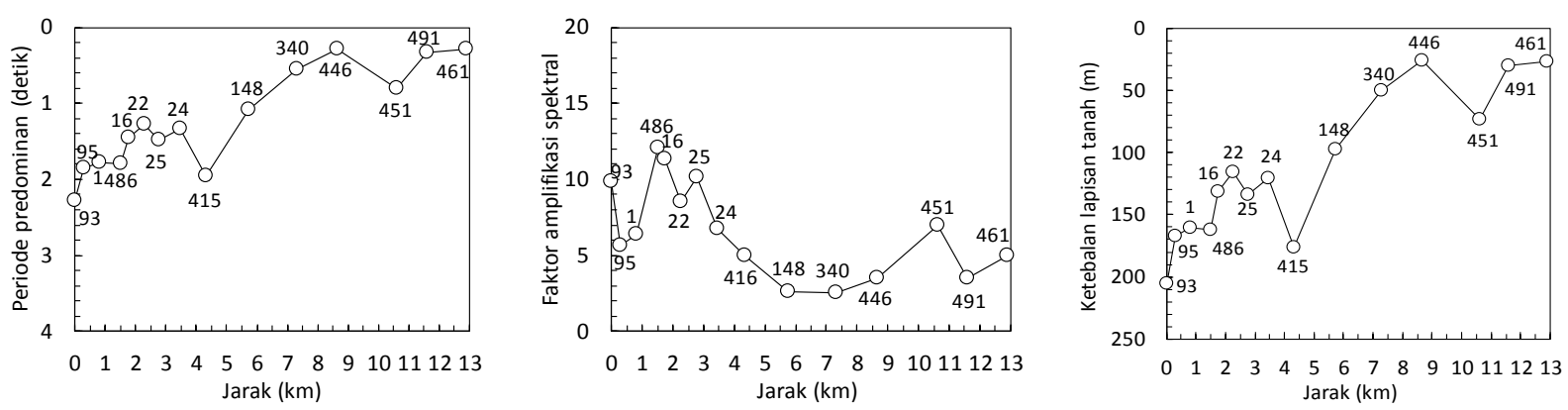

(a) Profil periode predominan, ketebalan tanah lunak lintasan A-A
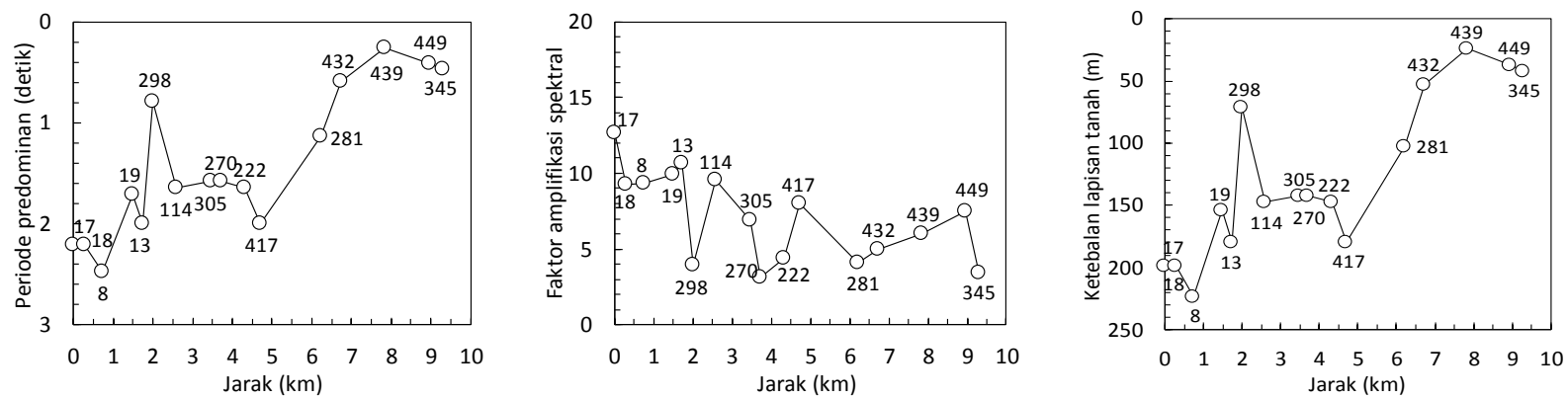

(b) Profil periode predominan, faktor amplifikasi dan ketebalan tanah lunak lintasan B-B
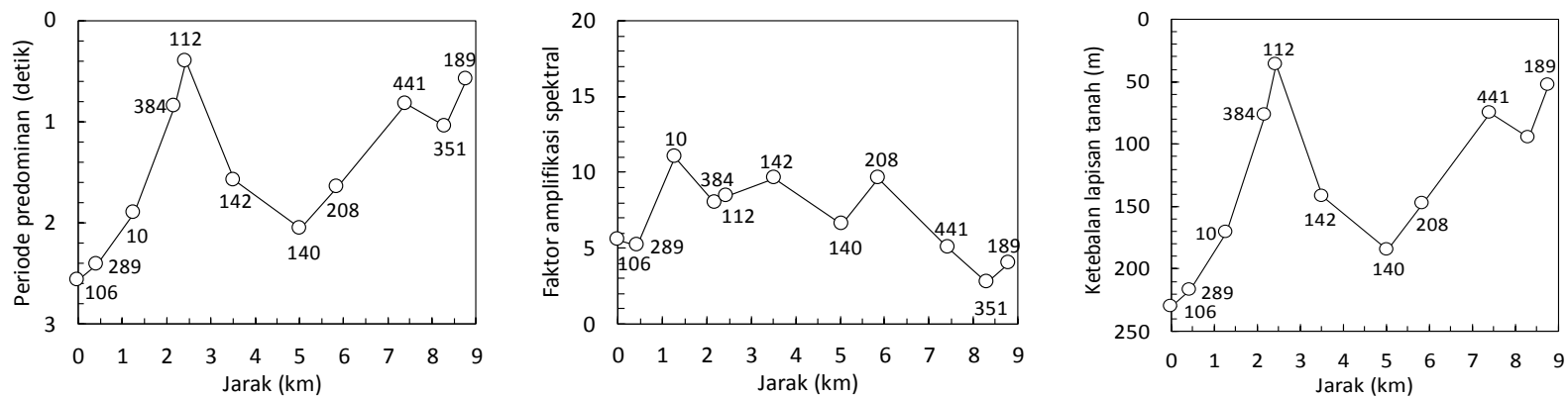

(c) Profil periode predominan, faktor amplifikasi dan ketebalan tanah lunak lintasan C-C
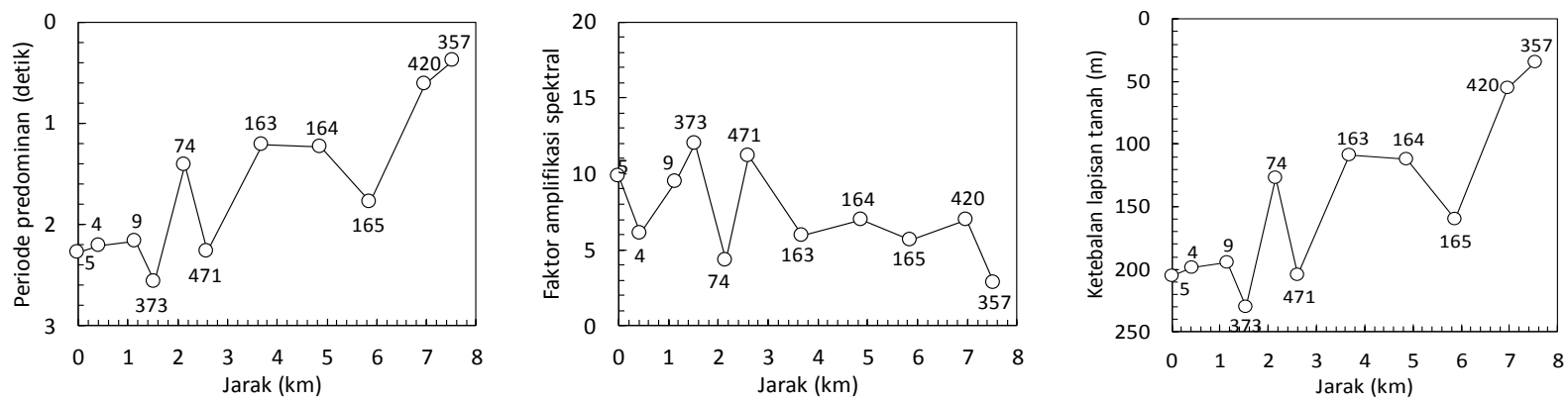

(d) Profil periode predominan, faktor amplifikasi dan ketebalan tanah lunak lintasan D-D

Gambar 8. Variasi nilai periode predominan, faktor amplifikasi tanah dan estimasi ketebalan lapisan tanah aluvial pada beberapa lintasan arah timurlaut-baratdaya.

Untuk menjelaskan pengaruh struktur bawah permukaan pada sifat dinamik tanah alluvial, ketebalan lapisan tanah alluvial lunak dihitung dengan menggunakan persamaan $T=4 H / V_{S}$, dimana $T$ adalah periode predominan tanah, $H$ adalah ketebalan lapisan tanah dan $V_{s}$ adalah kecepatan gelombang geser $\left(V_{s}\right)$ lapisan tanah keras yang diasumsikan sebesar $350 \mathrm{~m} /$ detik.

Gambar 8 menyajikan profil sifat dinamika dan ketebalan lapisan tanah. Posisi lintasan dapat dilihat pada Gambar 3. Semua profil ketebalan 
Tabel 1. Nilai periode predominan dan faktor amplifikasi tanah pada lokasi bangunan yang rusak berat hingga runtuh akibat getaran gempa bumi 2009.

\begin{tabular}{lccccc}
\hline \multirow{2}{*}{ Nama bangunan } & \multicolumn{1}{c}{ Koordinat UTM 47M } & $\begin{array}{c}\text { Tingkat } \\
\text { kerusakan }\end{array}$ & $\begin{array}{c}\text { Periode } \\
\text { predominan } \\
\text { (detik) }\end{array}$ & $\begin{array}{c}\text { Faktor } \\
\text { amplifikasi }\end{array}$ \\
\cline { 2 - 3 } Hotel Ambacang & 651253 & 9894472 & Runtuh & 1,95 & 10,35 \\
Hotel Bumi Minang & 651172 & 9894338 & Rusak berat & 3,00 & 22,0 \\
Gereja Katedral & 651064 & 9894252 & Rusak berat & 3,00 & 22,0 \\
Hotel Inna Muara & 650967 & 9894201 & Rusak berat & 1,64 & 14,18 \\
STIE Dharma Andalas & 653046 & 9895576 & Runtuh & 1,61 & 8,60 \\
Hotel Nuansa & 650596 & 9894157 & Runtuh & 1,86 & 12,88 \\
Kantor BAPPEDA Padang & 651422 & 9897467 & Runtuh & 3,30 & 16,30 \\
Kantor BBWS Sumatera V & 650853 & 9899339 & Runtuh & 2,16 & 14,01 \\
Kantor Badan Ketahanan Pangan & 651327 & 9897688 & Runtuh & 1,86 & 8,11 \\
$\begin{array}{l}\text { Kantor Dinas Kelautan dan } \\
\text { Perikanan Prop. Sumbar }\end{array}$ & 651812 & 9896134 & Runtuh & 2,44 & 10,00 \\
$\begin{array}{l}\text { Kantor Dirjen Pajak Wilayah } \\
\text { Sumbar dan Jambi }\end{array}$ & 651198 & 9898710 & Runtuh & 1,30 & 8,60 \\
\hline
\end{tabular}

lapisan tanah memperlihatkan bahwa lapisan tanah semakin menipis pada lokasi-lokasi mendekati daerah pegunungan. Sebaliknya, lapisan tanah aluvial yang berjarak kurang dari 5 $\mathrm{km}$ dari pinggir pantai menunjukkan variasi ketebalan di beberapa lokasi. Pada jarak $2 \mathrm{~km}$ dari pinggir pantai, lapisan tanah aluvial cenderung menipis sehingga menyebabkan nilai faktor amplifikasi tanah menjadi mengecil. Hal ini mengindikasikan keberadaan struktur bawah permukaan yang menghasilkan topografi tinggian di kedalaman 50 hingga $100 \mathrm{~m}$ di bawah permukaan tanah. Selain itu, profil ketebalan tanah juga memperlihatkan celah periode predominan tanah sebesar 1,0 hingga 1,5 detik pada jarak yang dekat, sebagaimana dapat dilihat antara lokasi 340 dan 415 pada lintasan A-A', antara lokasi 432 dan 417 pada lintasan B-B', antara 441 dan 140 pada lintasan C-C dan antara 420 dan 165 pada lintasan D-D'. Hal ini mengindikasikan perbedaan ketinggian lapisan batuan dasar. Keberadaan zona tinggian dan depresi di bawah permukaan tanah ini disebabkan oleh sesar normal tersembunyi di kedalaman dan lokasi-lokasi tersebut. Untuk itu, perlu dilakukan pemetaan lebih detil dengan menggunakan metode geofisika lainnya, seperti metode gayaberat dan magnetotelluric, untuk mendapatkan gambaran yang akurat dan jelas mengenai zona sesar di lokasi-lokasi tersebut.

\section{Kerentanan amplifikasi tanah}

Parameter utama yang digunakan dalam kajian resiko terhadap goncangan gempa bumi adalah amplifikasi getaran gempa bumi. Untuk mendapatkan zonasi faktor amplifikasi tanah untuk wilayah Kota Padang, maka dilakukan penentuan nilai faktor amplifikasi tanah di beberapa lokasi bangunan yang mengalami kerusakan berat di wilayah Kota Padang akibat gempa bumi tahun 2009 untuk mendapatkan hubungan antara nilai amplifikasi puncak dan derajat kerusakan sebagaimana disajikan pada Tabel 1. 
Tabel 2. Zonasi kerentanan amplifikasi.

\begin{tabular}{ccc}
\hline No. & $\begin{array}{c}\text { Nilai faktor } \\
\text { amplifikasi (A) }\end{array}$ & $\begin{array}{c}\text { Zonasi kerentanan } \\
\text { amplifikasi }\end{array}$ \\
\hline 1. & $<3,0$ & Sangat rendah \\
2. & $3,0<\mathrm{A} \leq 6,0$ & Rendah \\
3. & $6,0<\mathrm{A} \leq 9,0$ & Sedang \\
4. & $9,0<\mathrm{A} \leq 12,0$ & Tinggi \\
5. & $>12,0$ & Sangat tinggi \\
\hline
\end{tabular}

Berdasarkan Tabel 1, bangunan yang rusak berat hingga roboh umumnya berada pada wilayah yang memiliki faktor amplifikasi tanah lebih besar dari 12. Menggunakan hasil pemetaan ini, maka disusun klasifikasi zonasi amplifikasi tanah berdasarkan nilai faktor amplifikasi sebagaimana disajikan pada Tabel 2. Menggunakan klasifikasi zonasi ini, maka dihasilkan peta mikrozonasi kerentanan amplifikasi getaran tanah Kota Padang (Gambar 7). Berdasarkan peta mikrozonasi tersebut, sebagian besar wilayah Kota Padang berada pada zonasi kerentanan amplifikasi sedang hingga tinggi, terutama di wilayah Koto Tangah, Nanggalo dan Padang Utara. Sementara wilayah Padang Utara bagian selatan, Padang Barat bagian selatan, Padang Timur bagian selatan, dan Padang Selatan bagian utara termasuk dalam zonasi kerentanan amplifikasi tinggi hingga sangat tinggi.

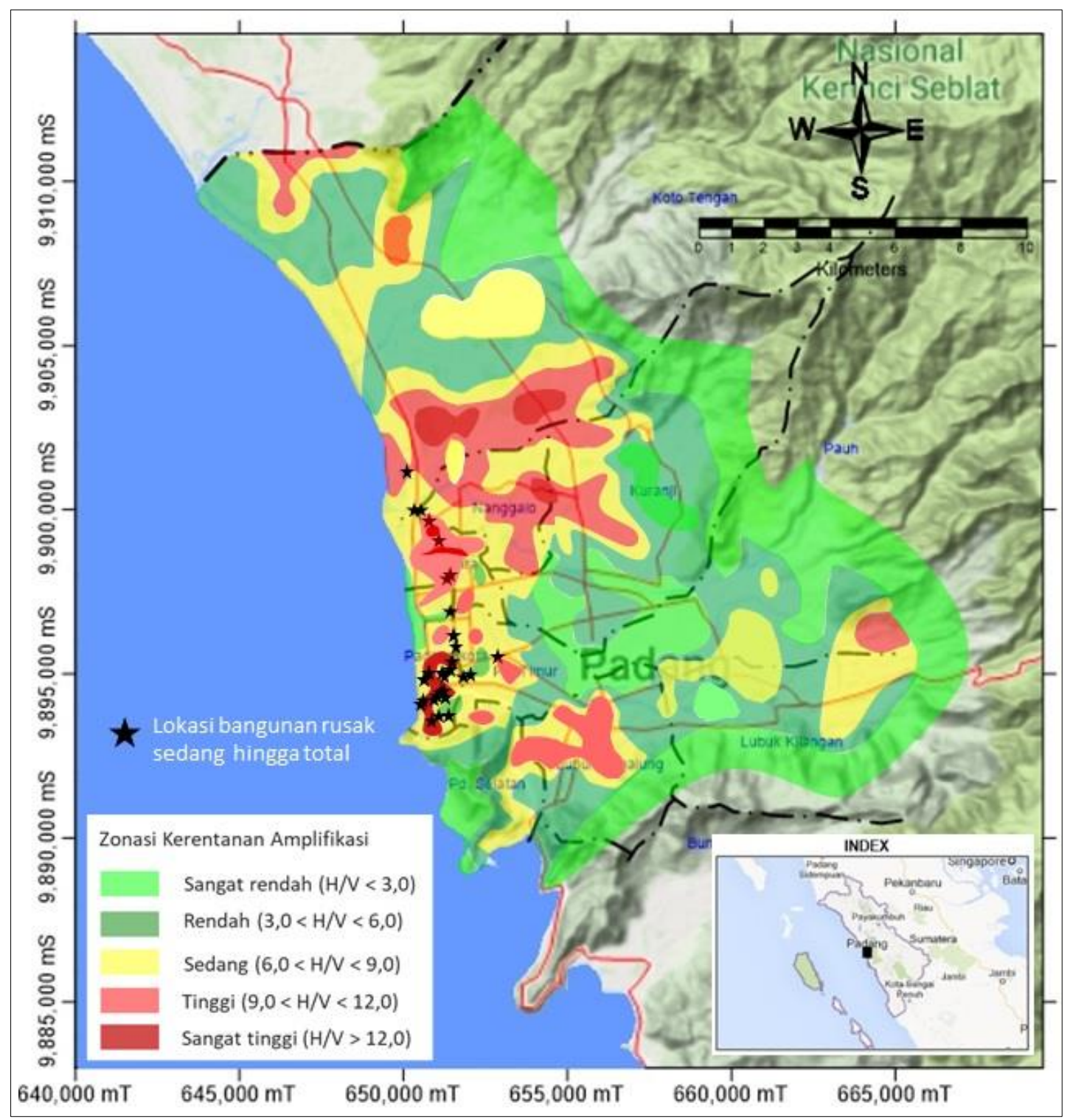

Gambar 9. Peta mikrozonasi kerentanan amplifikasi wilayah Kota Padang berdasarkan nilai faktor amplifikasi tanah. 
Tabel 3. Ringkasan zonasi kerentanan amplifikasi getaran untuk setiap kecamatan di Kota Padang.

\begin{tabular}{|c|c|c|c|}
\hline No & Kecamatan & $\begin{array}{c}\text { Kerentanan amplifikasi } \\
\text { getaran }\end{array}$ & $\begin{array}{c}\text { Peruntukan kawasan di wilayah } \\
\text { kecamatan* }\end{array}$ \\
\hline 1 & Koto Tangah & $\begin{array}{l}\text { Kerentanan sangat rendah - } \\
\text { tinggi }\end{array}$ & $\begin{array}{l}\text { Ruang terbuka hijau, perumahan } \\
\text { kepadatan sedang, perdagangan dan jasa, } \\
\text { perkantoran, pariwisata }\end{array}$ \\
\hline 2 & Pauh & $\begin{array}{l}\text { Kerentanan sangat rendah - } \\
\text { sedang }\end{array}$ & $\begin{array}{l}\text { Ruang terbuka hijau, perumahan } \\
\text { kepadatan rendah }\end{array}$ \\
\hline 3 & Kuranji & $\begin{array}{l}\text { Kerentanan sangat rendah - } \\
\text { tinggi }\end{array}$ & $\begin{array}{l}\text { Ruang terbuka hijau, perumahan } \\
\text { kepadatan sedang }\end{array}$ \\
\hline 4 & Nanggalo & Kerentanan sedang - tinggi & Perumahan kepadatan tinggi \\
\hline 5 & Padang Utara & Kerentanan sedang - tinggi & $\begin{array}{l}\text { perumahan kepadatan tinggi, } \\
\text { perdagangan dan jasa, perkantoran }\end{array}$ \\
\hline 6 & Padang Barat & $\begin{array}{l}\text { Kerentanan sedang - sangat } \\
\text { tinggi }\end{array}$ & $\begin{array}{l}\text { Cagar budaya, perumahan kepadatan } \\
\text { tinggi, perdagangan dan jasa }\end{array}$ \\
\hline 7 & Padang Timur & Kerentanan rendah - tinggi & $\begin{array}{l}\text { perumahan kepadatan tinggi, } \\
\text { perdagangan dan jasa, perkantoran }\end{array}$ \\
\hline 8 & Padang Selatan & $\begin{array}{l}\text { Kerentanan sangat rendah - } \\
\text { tinggi }\end{array}$ & $\begin{array}{l}\text { Cagar budaya, perumahan kepadatan } \\
\text { tinggi, perdagangan dan jasa, pariwisata }\end{array}$ \\
\hline 9 & Lubuk Kilangan & $\begin{array}{l}\text { Kerentanan sangat rendah - } \\
\text { sedang }\end{array}$ & $\begin{array}{l}\text { Ruang terbuka hijau, perumahan } \\
\text { kepadatan rendah }\end{array}$ \\
\hline 10 & Lubuk Begalung & $\begin{array}{l}\text { Kerentanan sangat rendah - } \\
\text { tinggi }\end{array}$ & $\begin{array}{l}\text { Ruang terbuka hijau, perumahan } \\
\text { kepadatan rendah, industri }\end{array}$ \\
\hline 11 & Bungus Teluk Kabung & Belum dipetakan & $\begin{array}{l}\text { Ruang terbuka hijau, perumahan } \\
\text { kepadatan rendah, industry, pariwisata }\end{array}$ \\
\hline
\end{tabular}

Berdasarkan hasil pemetaan lokasi bangunan yang mengalami kerusakan akibat gempa bumi 30 September 2009, maka semua bangunan yang mengalami kerusakan berat hingga total berada pada zonasi amplifikasi getaran tinggi hingga sangat tinggi (Gambar 7). Dengan demikian, pemetaan mikrozonasi amplifikasi secara umum sesuai dengan fenomena kerusakan bangunan yang terjadi di Kota Padang pada saat gempa bumi 2009.

Tabel 3 menyajikan ringkasan zonasi kerentanan amplifikasi getaran untuk setiap kecamatan di Kota Padang. Secara rinci mikrozonasi kerentanan amplifikasi getaran adalah sebagai berikut:

- Zonasi kerentanan amplifikasi sangat rendah, yang meliputi wilayah perbukitan di Kecamatan Koto Tangah, Kuranji, Pauh,
Padang Selatan, Lubuk Kilangan, Lubuk Begalung.

- Zonasi kerentanan amplifikasi rendah, yang meliputi wilayah di Kelurahan Pasir Nan Tigo, Bungo Pasang, Dadok Tunggul Hitam, Baitipuh Panjang, Lolong Belanti, Padang arai, Kuranji, dan Limau Manis.

- Zonasi kerentanan amplifikasi sedang, yang meliputi wilayah di Kelurahan Gunung Sariek, Jati, Olo, Sungai Sapieh, Lubuk Buaya, Parupuk Tabing, Air Tawar Barat dan Padang Sarai.

- Zonasi kerentanan amplifikasi tinggi, yang meliputi wilayah di Kelurahan Baitipuh Panjang, Flamboyan, Parak Laweh, Andalas, Air Tawar Timur, Berok Nipah dan Kampung Jao. 
- Zonasi kerentanan amplifikasi sangat tinggi, yang meliputi wilayah di Kelurahan Belakang Tangsi, Sawahan, Ulak Karang Utara, dan Kp. Lapai

Berdasarkan hasil mikrozonasi kerentanan amplifikasi tanah ini, maka pola ruang Kota Padang berdasarkan RTRW Kota Padang tahun 2010 - 2030 memerlukan penyempurnaan karena belum memasukkan aspek kerawanan amplifikasi goncangan gempa bumi di wilayah ini. Hal ini karena beberapa kawasan perumahan, perkantoran, perdagangan dan jasa berada pada zona kerentanan menengah hingga sangat tinggi (Tabel 3). Penyesuaian pola ruang ini dapat memperkecil dampak dari amplifikasi sehingga mengurangi kerusakan bangunan dan infrastruktur, dan korban jiwa akibat gempa bumi. Selain itu, perlu dilakukan penguatan struktur bangunan yang sudah ada agar tahan terhadap goncangan gempa, pembatasan tinggi bangunan yang menggunakan pondasi dangkal dan kontruksi pondasi dalam untuk bangunanbangunan bertingkat di beberapa wilayah rentan amplifikasi sedang hingga sangat tinggi. Hasil pemetaan kerusakan bangunan akibat gempa bumi di Kota Padang tahun 2009 menunjukkan bangunan bertingkat lebih dari 2 lantai dengan pondasi dangkal cenderung mengalami kerusakan parah akibat kegagalan struktur lantai dasar untuk menahan total beban bangunan.

\section{KESIMPULAN}

Makalah ini menyajikan analisis data pengukuran mikrotremor yang dilakukan di 499 lokasi di wilayah Kota Padang untuk menghasilkan zonasi kerentanan seismik wilayah ini. Berdasarkan hasil analisis rasio spektral horisontal dan vertikal (H/V), diketahui bahwa:

Respon spektra H/V lapisan tanah sangat bervariasi secara spasial, dengan nilai periode predominan dan berkisar $0,4-3,5$ detik, dan faktor amplifikasi dapat mencapai nilai 15 .

Nilai periode predominan dan faktor amplifikasi tanah sangat bergantung kepada jenis lapisan tanah/ batuan. Daerah pesisir, yang tersusun oleh material aluvial cenderung mempunyai periode predominan dan fakor amplifikasi yang lebih tinggi dibandingkan daerah lereng perbukitan yang disusun oleh material kipas aluvial dan material vulkanik.
Analisa respon spectra menunjukkan keberadaan zona tinggian dan depresi di bawah permukaan lapisan material aluvial. Hal ini mengindikasikan struktur bawah permukaan juga menjadi faktor pengontrol respon spectra lapisan tanah di wilayah Kota Padang.

Berdasarkan variasi dan sebaran nilai faktor amplifikasi, wilayah Kota Padang dapat diklasifikasikan menjadi 5 zona kerentanan amplifikasi dari kerentanan sangat rendah hingga sangat tinggi. Bangunan-bangunan yang rusak sedang hingga runtuh pada gempa bumi Padang tahun 2009 berada pada zona kerentanan amplifikasi tinggi hingga sangat tinggi.

Hasil studi ini merekomendasikan revisi rencana tata ruang Kota Padang dengan mempertimbangkan aspek amplifikasi getaran gempa dan upaya mitigasi bahaya gempa bumi dengan perkuatan struktur bangunan-bangunan di zona kerentanan sedang hingga sangat tinggi untuk mengurangi kerusakan bangunan dan korban jiwa akibat peristiwa gempa bumi besar di masa mendatang.

\section{UCAPAN TERIMA KASIH}

Penulis mengucapkan terima kasih kepada Japan International Cooperation Agency (JICA) atas bantuan peralatan mikrotremor untuk penelitian ini. Kami juga mengucapkan terima kasih disampaikan kepada Profesor Kohji Tokimatsu dari Tokyo Institute of Technology, Jepang yang telah memberikan bimbingan penggunaan peralatan dan pengolahan data mikrotremor. Ucapan terima kasih disampaikan kepada Bappeda Kota Padang atas dukungan perizinan untuk pelaksanaan penelitian di Kota Padang pada tahun 2010-2014.

\section{DAFTAR PUSTAKA}

Ansal, A., 2004. Recent Advances in Earthquake Geotechnical Engineering and Microzonation. Kluwer Academic Publishers, Dordrecht, 354 pp.

Bramerini, F., Castenetto, S., dan Naso, G., 2015. Guidelines for seismic microzonation. Conference of Regions and Autonomous Provinces of Italy - Civil Protection Department, Rome, 120 pp.

Bonnefoy-Claudet, S., Leyton, F., Baize, S., Berge-Thierry, C., Bonilla, L. F., Campos, J., 2008. Potentiality of 
microtremor to evaluate site effects at shallow depths in the deep basin of Santiago De Chile. Proc. 14th WCEE Beijing, China, http://www.iitk.ac.in /nicee/wcee/fourteenth_conf_china.

Claprood, M., Asten, M. W., 2008. Microtremor survey methods in the Tamar Valley, Launceston, Tasmania: evidence of 2D resonance from microtremor observations. Proc. Earthquake Engineering in Australia Conference, AEES, Ballarat, November 2008, Paper 20.

Davenport, P. N., Stephenson, W. R., 2005. Use of microtremors to assess local site effects. Proc. NZSEE Conference, Wairakei Resort, Taupo, New Zealand, 9, 11-13.

EERI 2009. - The Mw 7.6 Western Sumatra earthquake of September 30, 2009. Special Earthquake Report - December 2009.

Eskisar, T., Özyalin, S., Kuruoğlu, M., Yilmaz, H. R., 2013. Microtremor measurements in the Northern Coast of 'Izmir Bay, Turkey to evaluate site-specific characteristics and fundamental periods by $\mathrm{H} / \mathrm{V}$ spectral ratio method. Journal of Earth System Science, 122(1), 123-136.

Fallahi, A., Alaghebandian, R. Miyajima, M., 2003. microtremor measurements and building damage during the ChangurehAvaj, Iran Earthquake of June 2002. Journal of Natural Disaster Science, 25(1), 37-46.

Gosar, A. J., 2009. A microtremor HVSR study of the seismic site effects in the area of the town of Brezice (SE Slovenia). Acta Geotechnica Slovenica, 2, 31-45.

Kamawan, Marjiyono, Setianegara, R., Effendi, I., Mulyati, N., 2009. Penelitian mikrotremor Kota Padang dan sekitarnya, Sumatera Barat. Laporan Akhir, Program Dinamika Kuarter, Pusat Survei Geologi, Badang Geologi, KESDM, Bandung, 49 hal.

Kiyono, J., Ono, Y., Sato, A., Noguchi, T., Putra, R. R., 2011. Estimation of subsurface structure based on microtremor observations at Padang, Indonesia.
ASEAN Engineering Journal, Part C, 1 (3), 66-81.

Lermo, J., Chavez-Garcia, F. J., 1993. Site effect evaluation using spectral ratios with only one station. Bulletin of the Seismological Society of America, 83, 1574-1594.

McCaffrey, R., 1991. Slip vectors and stretching of the Sumatran fore arc. Geology, 19, 881- 884 .

Nakamura, Y., 1989. A method for dynamic characteristics estimation of subsurface using microtremor on the ground surface. Quarterly Report, Railway Technical Reseach Institute, 30, 25-33.

Natawidjaja, D. H., Sieh, K., Ward, S. N., Cheng, H., Edwards, R. L., Galetzka, J., Suwargadi B. W., 2004. Paleogeodetic records of seismic and aseismic subduction from Central Sumatran microatolls, Indonesia. Journal of Geophysical Research, 109, B04306, DOI: 10.1029/2003JB 002398.

Natawidjaja, D. H., Triyoso, W., 2007. The Sumatran fault zone - from source to hazard. Journal of Earthquake and Tsunami, 1(1), 21-47.

Prawirodirdjo, L., Bock, Y., Genrich, J., Puntodewo, S. S. O., Rais, J., Subarya, C., Sutisna, S., 2000. One century of tectonic deformation along the Sumatran fault from triangulation and global positioning system surveys, Journal of Geophysical Research, 105, 67796796.

Seed, H. B., Romo, M. P., Sun, J. I., Jaime, A., Lysmer, J., 1988/ The Mexico earthquake of September 19, 1985 Relationships between soil conditions and earthquake ground motions. Earthquake Spectra, 4, 687-729.

Sieh, K., Natawidjaja, D. H., 2000. Neotectonics of the Sumatran fault, Indonesia. Journal of Geophysical Research, 105, 28295-28326.

Tuladhar, R., Yamazaki, F., Warnitchai, P., Saita, J., 2004. Seismic microzonation of the greater Bangkok area using microtremor 
observations. Earthquake Engineering and Structural Dynamic, 33, 211-225 DOI: 10.1002/eqe.345.

Tohari, A., Sugianti, K., Soebowo, E., 2011. Liquefaction potential at Padang City: a comparison of predicted and observed liquefaction during the 2009 Padang earthquake. Journal Riset dan Pertambangan, 21(1), 7-18. 